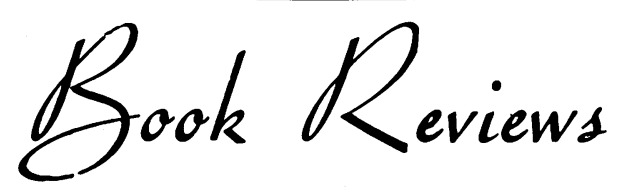

\section{THE BIOCHEMICAL RESPONSE TO INJURY \\ A Symposium Organized by the Council for International Organization of Medical Sciences}

Edited by $H$. B. STONER, with the assistance of C. J. Threlfall. Pp. $467+x i$. Oxford: Blackwell Scientific Publications. 1960. 57s. 6d.

An international symposium on the metabolic effects of injury was held in Austria in 1958 . This volume collects the papers read at this symposium, and includes a summary of the discussion that followed each paper, together with the general introduction by the chairman, Dr. D. P. Cuthbertson. A very full bibliography is given.

The contributors are all acknowledged experts in their own fields, and hail from many different countries. However, all but one of the contributions is presented in English.

A wide range of subjects is considered; the terms of reference of the symposium have been most liberally interpreted. For example, Dr. A. Fonnesu shows how in cloudy swelling an anatomical change in the mitochondria (as revealed by the electron microscope) is associated with an alteration in carbohydrate metabolism, whereby aerobic glycolysis increases; while Dr. R. Fahraeus discusses the possible importance of intravascular aggregation of erythrocytes in the production of tissue damage in shock. The difficult problem of irreversible shock is tackled by Drs. A. G. B. Kovach and Dr. A. Fonyo from the viewpoint of changes in the cerebral circulation, and by Dr. J. Fine and his collaborators from the viewpoint of bacterial toxins absorbed from the intestine. The particular interests of the clinician are catered for by several contributors, notably Dr. V. Wynn, who discusses some problems of water metabolism after surgery, and Dr. S. M. Rosenthal, who deals with the clinical treatment of shock.

This book is essential reading for anyone who wants to know the present position with regard to research into shock; and it will be most useful to workers in any one section of the field who wish to see how their own work integrates with that of students in many different disciplines. Perhaps most important of all, the book is an object lesson in how the proceedings of such a symposium should be presented in book form. The editors and publishers are to be congratulated upon a notable achievement.

\section{ARTHRITIS: GENERAL PRINCIPLES, PHYSICAL MEDICINE AND REHABILITATION}

Edited by Edward W. Lowman, M.D. Pp. 292, illustrated. London: J. \& A. Churchill Ltd. 1959. 68s.

This book deals with the problem of the arthritic rather than the problem of arthritis. It is written in two parts : part one deals with arthritis, part two with the physical medicine and rehabilitation treatment of arthritis.

The book is written by a team of experts. Part one is inadequate for the physician who may be a little surprised to see the use of gold salts advocated and discussed at great length for the treatment of the rheumatoid arthritic before trying the corti costeroids. Phenylbutazone is not mentionedo The chapter on psychogenic rheumatism is too long for a book of this nature. There is, however, an excellent chapter on range of motion testing and exercises and the principles of therapeutic exercises are well discussed, as is occupational therapy.

Valuable chapters are on wheel-chair prescription, and shoes and shoe correction. The illustrations of self-help devices are good. The chapter on rehabilitation of the arthritic cripple is excellent.

Not all will agree with the suggestion of using iontophoresis for the acute back.

The book is well illustrated throughout. It will not be of any great assistance to the experienced physician, but should be of help to medical auxiliaries and social workers concerned with the arthritic patient.

\section{A GUIDE TO THE IDENTIFICATION OF THE GENERA OF BACTERIA}

By V. B. D. Skerman. Pp. ix + 257. Baltimore: The Williams \& Wilkins Co. 1960. 44s.

This is a digest of Bergey's well-known manual which should be of value to bacteriologists whose interests extend beyond the medical limits. There is a useful section on 'Methods' which all bacteriologists should wish to have handy. 